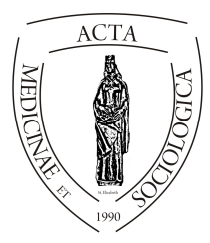

Acta Medicinae et

Sociologica (2020)

doi:

\title{
Coping Strategies of Elite Hungarian Junior Handball Players
}

\author{
Csaba Ökrös ${ }^{1}$, Dóra König-Görögh ${ }^{2}$, Noémi Gyömbér ${ }^{3}$ \\ ${ }^{1}$ Head of Department of Sport Games, University of Physical Education, 1123.Budapest, Alkotás u. 44. \\ ${ }^{2}$ Assistant Lecturer of University of Debrecen, Faculty of Education for Children and Special Educational Needs, \\ 4220. Hajdúböszörmény, Désány István u. 1-9. \\ ${ }^{3}$ Senior Lecturer of Department of Psychology and Sport Psychology, University of Physical Education, \\ 1123. Budapest, Alkotás u. 44.
}

\begin{tabular}{|c|c|}
\hline INFO & ABSTRACT \\
\hline $\begin{array}{l}\text { Dóra König-Görögh } \\
\text { kgoroghdora@gmail.com }\end{array}$ & \multirow[b]{2}{*}{$\begin{array}{l}\text { Abstract. Several studies provided instruments, with the } \\
\text { possibility to measure self-assessment and coping strategies. } \\
\text { This study aimed to study differences in coping strategies by } \\
\text { age groups and gender in handball players. For } \\
\text { psychological profile the Athletic Coping Skills Inventory } \\
\text { (ACSI-28) was applied, at elite Hungarian junior handball } \\
\text { teams (n=288) in 2016-2017. On the scales Coping with } \\
\text { Adversity and Freedom From worry males acquired } \\
\text { significantly higher average values, females showed higher } \\
\text { mean values of Goal Setting / Mental Preparation and } \\
\text { Coachability. On Freedom from Worry, the oldest players } \\
\text { performed the best, Coachability was highest in the youngest } \\
\text { group. High values of Concentration were measured by } \\
\text { playmakers, which was significantly higher than that of } \\
\text { other offensive roles. With the results of our study, we } \\
\text { would like to draw attention to the fact that for successful } \\
\text { preparation, the knowledge of the athlete's coping skills and } \\
\text { theirself-knowledge are in dispensable. }\end{array}$} \\
\hline $\begin{array}{l}\text { Keywords: } \\
\text { copingstrategies, } \\
\text { handball, adolescences }\end{array}$ & \\
\hline $\begin{array}{l}\text { Kulcsszavak: } \\
\text { kézilabda, utánpótlás, } \\
\text { megküzdési stratégiák }\end{array}$ & $\begin{array}{l}\text { Absztrakt. Jelen tanulmányunkban magyar utánpótlás korú } \\
\text { (14-19 éves) kézilabdázók ( } \mathrm{n}=288) \text { sportolói megküzdési } \\
\text { stratégiáit vizsgáltuk a nemek, életkorok és a kézilabda posz- } \\
\text { tok tekintetében, AthleticCopingSkillsInventory (ACSI-28) } \\
\text { segítségével. A Csapásokkal való megküzdés ( } 11,69 \text { vs. 11,00; } \\
\mathrm{F}=2,670 \mathrm{p}<0,01) \text { és a Szorongásmentesség ( } 9,94 \text { vs. 9,12; } \\
\mathrm{F}=2,670 \mathrm{p}<0,01) \text { skálákon a férfiak értek el szignifikánsan } \\
\text { magasabb átlagot. Ezzel szemben a nök magasabb átlagot } \\
\text { mutattak a Célkitüzés/mentális felkészültség ( } 12,12 \text { vs. } 11,56 \text {; } \\
\mathrm{F}=-2,121 \mathrm{p}<0,05) \text { és az Edzö által irányithatóság (13,28 vs. } \\
12,12 ; \mathrm{F}=-4,107 \mathrm{p}<0,01) \text {. A Szorongásmentesség (10,55 vs. } \\
9,88 \text { vs. } 8,83 ; \mathrm{F}=6,880 \mathrm{p}<0,01) \text { skálán a legidősebb játékosok }\end{array}$ \\
\hline
\end{tabular}




\begin{abstract}
érték el a legmagasabb értékeket. Az Edzö által irányithatóság $(\mathrm{F}=9,617 \mathrm{p}<0,01)$ a legfiatalabbak körében volt a legmagasabb. A kézilabda posztok alapján megállapíthatjuk, hogy a Koncentráció $(\mathrm{F}=2,612 \mathrm{p}<0,05)$ és az Önbizalom/teljesitmény motiváció $(\mathrm{F}=3,067 \mathrm{p}<0,05)$ skálákon mutatkoztak szignifikáns különbségek a csoportátlagokban. A Koncentráció tekintetében az irányítóknál látunk magas átlagot, amely szignifikánsan magasabb, mint a többi támadó poszton játszók esetében. Az Önbizalom esetében a szélsők csoportjában találhatóak a legmagasabb értékek. A tanulmányunk eredményeivel arra szeretnék felhívni a figyelmet, hogy az edzőknek a sikeres felkészülés érdekében figyelembe kell venniük a játékosaik nemét, életkorát, posztját, hiszen a teljesítmény növeléséhez elengedhetetlen a sportoló megküzdési képességeinek ismerete és a játékos önismerete.
\end{abstract}

\title{
Introduction
}

In order to achieve improved sports performance, athletes and coaches should learn to raise and maintain players' emotional level (Gyömbér and Kovács, 2012), as emotions can significantly influence performance (Leunes, 2011). With changes in fitness, psychological mechanisms and further functions may be altered as well (Révész, 2008). Motivation, coping strategies, sensing the motivational environment, stress tolerance and the ability of adaptation may influence the success of the contestants' preparation (Révész, 2008). The question arises:-; can we identify what kind of coping skills should players have in terms of handball playing positions? Are there any differences in age group and gender? In our opinion through the help of sport psychology, young handball players can reach increased levels of performance and become more advanced adult players. In this paper it is our aim is to investigate coping skills among junior handball players in terms of age, gender and player position.

\section{Team sports and ACSI-28}

In recent times, numbers of researches in athletes' coping strategies have increased. Several studies have provided instruments to measure self-assessment and coping strategies. Goudas (1998) studied coping strategies of basketball players' using the Athletic Coping Skills Inventory-28 (ACSI-28) questionnaire (Smith et al, 1995). The study showed that players with more experience reached higher scores on the 7 scales e.g., Coping with Adversity; Peaking under Pressure; Goal Setting, Mental Preparation; Concentration; Freedom from Worry; Confidence and Achievement Motivation; Coachability than their less experienced co-athletes. Similar conclusions were drawn in the research of Bebetsos and Antoniu (2003), where older - more experienced - badminton players achieved higher scores. Milavi et al. (2017) examined youth female volleyball positional differences in psychological coping skills $(n=180)$. There were no significant age and positional differences in scales of 
ACSI-28, suggesting that the levels of psychological coping skills do not change as playing experience increases. Ciocan, Fleancu\&Ciocan (2012) tried to determine the psychological skills relevant to professional volleyball players in Division A. Through the competition, the coaches introduced a psychological model in the team's training to increase the players' psychological skills. Volleyball players' psychological skills improved, they cannot generalize with regard to the development of psychological skills. In their opinion the scores and increases recorded vary according to each athlete's personality.

Studies by Coetzee et al. (2006), Orosz (2009), Jooste, Steyn\& Van den Berg (2014), Kiss et al. (2015), Csáki et al. (2017) described the coping skills of soccer players. The successful soccer players obtained higher scores for the striving for psychological skill compared to the less successful players, with the most important discriminators between these groups being Concentration, Peaking under pressure, and Goal setting (Coetzee et al., 2006). On the other hand Jooste et al. (2014) found negative correlation between psychological skills and team success. Surveying football players and their coaches, Orosz (2009) measured significant differences in talent-levels on all scales, except for Peaking under Pressure and Coachability. Kiss et al. (2015) also studied coping strategies of football players (age group of 16-20 years), where Peaking under Pressure, Concentration and Confidence and Achievement Motivation all showed high average values (compared to other scales). Between age groups, only Goal Setting and Mental Preparation showed significant differences, U18 group showed significantly lower scores than U16 or U17. In different soccer playing positions there were insignificant differences in scales of ACSI-28 (Jooste et al., 2014, Csáki et al., 2017).

Grobbelaar \&Eloff (2011) also investigated the differences regarding the psychological skills playing positions in team sports (soccer, basketball, rugby, American football). Their results showed that the goal attack and wing defence players outperformed the other positional groups (goal shooter, wing attack, centre, goal defence, goal keeper).

In their research Bognár et al. (2009) focused on coping skills, motivational profiles, perceived motivational climate in elite U18 male ice hockey and soccer players. Their result revealed that the ice-hockey players demonstrated higher levels of Freedom from Worry and Coachability than soccer players. Géczi (2009) found a significant difference in Freedom from Worry between ice-hockey players of the national team and non-national team players, suggesting that players in the national team showed less worry. He also found higher scores of Peaking under Pressure, Concentration and Confidence and Achievement Motivation than on other scales.

\section{Experience by ACSI-28}

Wapels (2003) emphasized that gymnasts competing on higher levels performed exceptionally on the scales of Confidence and Achievement Motivation, Coachability and Concentration. In his study, Révész (2008) underlined a significant difference between accomplished and underperforming groups of swimmers on the Peaking under Pressure scale. Tóth et al. (2011) found a significant difference between adult and U18 ice-hockey players on the same scale. In addition to experience, a crucial factor in sport performance, Gyömbér et al. (2015) pointed out gender differences in 
scores as well. They studied athletes of different ages, genders and sports, and their findings showed that men acquired higher scores on all scales with the exception of Coachability. Results based on age differences - in accordance with the literature-, suggested that older athletes acquired higher scores on the ACSI-28 scales, except for Concentration and Mental Preparation.

Effects of mental training on coping skills (by ACSI-28)

Vidic\& Burton (2010) observed the impact of an 8-week goal setting program by female tennis players from Division I $(n=6)$. After the training all players demonstrated improvements in motivation, confidence and performance measures. Vidic, Martin \&Oxhandler in 2016 made another intervention with female basketball players from Division I. The study conducted a ten-session mindfulness-based intervention for 1 hour per week over the course of 16 weeks. Their results showed a decrease in stress, and an increase in athletic coping skills over the course of the intervention. Ragab's study (2015) focused on the effects of mental toughness training on coping skills and shooting effectiveness in male handball players. There were two groups: in the experimental group $(n=10)$ the players participated in the mental toughness training program, 3 times a week for 8 weeks. The players in the control group $(n=8)$ participated only in the traditional program. There were significant differences in overall ACSI-28 scales between pre-, and post training in the experimental group.

\section{Aim of the study}

To contribute to the growing body of contemporary literature, our study aimed to study differences in coping strategies by age groups and gender in handball players. Moreover, the research questions focused on differences measured between handball players of different posts. In our present study, coping strategies of Hungarian junior handball players by gender, age and role were investigated.

\section{Methods}

\section{Procedure}

A questionnaire survey was conducted in the training period of 2016-2018 among junior handball players $(n=288)$. The questionnaires were distributed in elite Hungarian junior handball teams. In this study only players from teams who played in the first class in this period (11 teams) could participate, for this selection we chose the stratified sampling procedure. Participants were informed about the study objectives. Filling in the questionnaires took approximately 20 minutes. Voluntary and anonymous participation was ensured in the study, noting that data that was being collected and would be used for research purposes only. 


\section{Measurement instruments}

Sociodemographic features were measured in the first section of the survey. Besides gender ( $1=$ male, $2=$ female), age was recorded in years of age at the time of participation. Age groups were calculated for subsequent analyses - based on the distribution of years of age - in order to provide satisfactory number of cases $(1=14-$ 15 years old, $2=16-17$ years old, $3=18-19$ years old). The posts of junior handball players were recorded. Playing posts were coded 1=goalkeeper (GK), 2=backcourt player (BP), 3=playmaker (PM), 4=winger (WI), 5=pivot (PI).

Athletic Coping Skills Inventory (ACSI-28) is ameasurement instrument for athletes' psychological skills, developed by Smithet al. (1994). Athletic Coping Skills Inventory consists of 28 items (e.g. "On a daily or weekly basis, I set very specificgoals for myself that guide what I do"; "When I fail to reachmy goals, it makes me try even harder") that are assessed bya 4-point Likert-type scale where 0 $=$ almost never to $3=$ almost always. ACSI- 28 items measure 7 scales: Coping withAdversity, Coachability, Concentration, Confidence andAchievement Motivation, Goal Setting and Mental Preparation, Peaking under Pressure and Freedom from Worryscales. Cronbach's alpha showed reliability of $\alpha=.715$ in the present study.

Analysis

Statistical analyses were carried out by using IBM SPSS 22.0 software. For descriptive statistics, frequencies, crosstabs were run, and in the next steps independent samples t-tests, Chi-square, correlation analysis, and ANOVA tests were employed. The level of significance was set to .05 . Analyses focused to reveal differences in coping by sociodemographic characteristics and player posts.

\section{Results}

Among coping items, Coachability $(\mathrm{M}=12.84)$, Peaking under Pressure $(\mathrm{M}=12.42)$, and Confidence/Achievement Motivation ( $\mathrm{M}=12.34)$ showed the highest values, while the lowest value was measured on Freedom from Worry (M=9.43).

\begin{tabular}{|l|l|l|}
\hline & Mean (S.D.) & Range \\
\hline Coping withAdversity & $11.26(2,3)$ & $1-16$ \\
\hline Peaking under Pressure & $12.42(2,5)$ & $5-16$ \\
\hline Goal Setting and Mental Preparation & $11.91(2,2)$ & $4-16$ \\
\hline Concentration & $12.28(2,0)$ & $4-16$ \\
\hline Freedom from Worry & $9.43(2,7)$ & $4-16$ \\
\hline Confidence andAchievement Motivation & $12.34(1,9)$ & $7-16$ \\
\hline Coachability & $12.84(2,3)$ & $5-16$ \\
\hline
\end{tabular}

Table 1 - Descriptive statistics $(\mathrm{n}=288)$

In the next step coping scales were analyzed by gender and age groups, and additionally by handball posts. 


\begin{tabular}{|c|c|c|c|c|c|}
\hline & \multicolumn{2}{|c|}{ Gender $^{1}$} & \multicolumn{3}{|c|}{ Age groups ${ }^{2}$} \\
\hline & Male & Female & U14-U15 & U16-U17 & U18-U19 \\
\hline Coping with Adversity & $\begin{array}{l}11.69 \\
(1,9)^{* *}\end{array}$ & $\begin{array}{l}11.00 \\
(2.5)\end{array}$ & $\begin{array}{l}11,39 \\
(2.4)\end{array}$ & $\begin{array}{l}11.14 \\
(2.3)\end{array}$ & $\begin{array}{l}11.33 \\
(2.4)\end{array}$ \\
\hline Peaking under Pressure & $\begin{array}{l}12.69 \\
(2.2)\end{array}$ & $\begin{array}{l}12.26 \\
(2.7)\end{array}$ & $\begin{array}{l}12,42 \\
(2.8)\end{array}$ & $\begin{array}{l}12.41 \\
(24)\end{array}$ & $\begin{array}{l}12.46 \\
(2.4)\end{array}$ \\
\hline $\begin{array}{l}\text { Goal Setting and Mental } \\
\text { Preparation }\end{array}$ & $\begin{array}{l}11.56 \\
(2.2)^{*}\end{array}$ & $\begin{array}{l}12.12 \\
(2.2)\end{array}$ & $\begin{array}{l}11,99 \\
(2.2)\end{array}$ & $\begin{array}{l}11.97 \\
(2.1)\end{array}$ & $\begin{array}{l}1158 \\
(2.4)\end{array}$ \\
\hline Concentration & $\begin{array}{l}12.32 \\
(1.9)\end{array}$ & $\begin{array}{l}12.25 \\
(2.0)\end{array}$ & $\begin{array}{l}12,42 \\
(2.0)\end{array}$ & $\begin{array}{l}12.12 \\
(1.9)\end{array}$ & $\begin{array}{l}12.44 \\
(2.0)\end{array}$ \\
\hline Freedom from Worry & $\begin{array}{l}9.94 \\
(2.4)^{* *}\end{array}$ & $\begin{array}{l}9.12 \\
(2.8)\end{array}$ & $\begin{array}{l}9,88 \\
(2.9)^{* *}\end{array}$ & $\begin{array}{l}8.83 \\
(2.4)\end{array}$ & $\begin{array}{l}10.55 \\
(2.8)\end{array}$ \\
\hline $\begin{array}{l}\text { Confidence and } \\
\text { Achievement Motivation }\end{array}$ & $\begin{array}{l}12.36 \\
(1.8)\end{array}$ & $\begin{array}{l}12.33 \\
(2.0)\end{array}$ & $\begin{array}{l}12,60 \\
(1.9)\end{array}$ & $\begin{array}{l}12.09 \\
(2.0)\end{array}$ & $\begin{array}{l}12.52 \\
(1.7)\end{array}$ \\
\hline Coachability & $\begin{array}{l}12.12 \\
(2.4)^{* *}\end{array}$ & $\begin{array}{l}13.28 \\
(2.2)\end{array}$ & $\begin{array}{l}13,59 \\
(2.3)^{* *}\end{array}$ & $\begin{array}{l}12.28 \\
(2.3)\end{array}$ & $\begin{array}{l}12.92 \\
(2.0)\end{array}$ \\
\hline
\end{tabular}

Note: ${ }^{*} \mathrm{p}<.05,{ }^{*} \mathrm{p}<.01 ;{ }^{1}$ independent samples t-test, ${ }^{2}$ ANOVA

Table $2-$ Coping by gender and age groups $(\mathrm{n}=288)$

Table 2 shows a number of differences between male and female players in coping $(\mathrm{p}<.05)$. On the scales Coping with Adversity $\left(\mathrm{M}_{\text {male }}=11.69\right.$ vs. $\mathrm{M}_{\text {female }}=11.00$; $\mathrm{t}=2.670 \mathrm{p}<.01)$ and Freedom from Worry $\left(\mathrm{M}_{\text {male }}=9.94\right.$ vs. $\mathrm{M}_{\text {female }}=9.12 ; \mathrm{t}=2.670$ $\mathrm{p}<.01$ ), males acquired significantly higher values. In contrast, females showed higher mean values of Goal Setting and Mental Preparation $\left(\mathrm{M}_{\mathrm{female}}=12.12\right.$ vs. $\left.\mathrm{M}_{\text {male }}=11.56 ; \mathrm{t}=-2.121 \mathrm{p}<.05\right)$, and Coachability $\left(\mathrm{M}_{\text {female }}=13.28\right.$ vs. $\mathrm{M}_{\text {male }}=12.12 ; \mathrm{t}=$ $4.107 \mathrm{p}<.01)$.

Age groups were tested in two steps: first an analysis with dichotomous age variable (cut-off point by mean value) was run. This grouping based on mean age did not show significant differences, therefore in the second step we used the threegroup variant to reveal differences by different years of age within the junior category. Differences between the age groups showed that the oldest and the youngest junior players performed well on Freedom from Worry $\left(\mathrm{M}_{18}=10.55\right.$ vs. $\mathrm{M}_{15}=9.88$ vs. $\left.\mathrm{M}_{16-17}=8.83 ; \mathrm{F}=6.880 \mathrm{p}<.01\right)$ compared to the $16-17$ year old players. Coachability $(\mathrm{F}=9.617 \mathrm{p}<.01)$ was significantly higher in the youngest group, with junior handball players under 15 by reaching the mean value of $\mathrm{M}_{15}=13.59$, while players above 18 years achieved solely $\mathrm{M}_{18}=12.92$.

In the last step of the analyses, playing positions were thoroughly investigated. Analysis of variance (One-way ANOVA) was employed to reveal additional differences in coping by playing positions of junior handball players. 


\begin{tabular}{|l|l|l|}
\hline & \multicolumn{2}{|c|}{ Playing Positions } \\
\hline Coping with Adversity & Goalkeeper & $10.52(2.5)$ \\
& Backcourt player & $11.12(2.2)$ \\
& Playmaker & $11.67(2.2)$ \\
& Winger & $11.43(2.5)$ \\
& Pivot & $11.45(1.9)$ \\
\hline Peaking under Pressure & Goalkeeper & $12.00(2.6)$ \\
& Backcourt player & $12.66(2.3)$ \\
& Playmaker & $12.75(2.8)$ \\
& Winger & $12.42(2.7)$ \\
& Pivot & $12.12(2.2)$ \\
\hline Goal Setting and Mental Preparation & Goalkeeper & $11.31(2.4)$ \\
& Backcourt player & $11.87(2.3)$ \\
& Playmaker & $12.33(1.8)$ \\
& Winger & $12.09(2.1)$ \\
& Pivot & $11.69(2.4)$ \\
\hline Concentration & Goalkeeper & $12.05(2.0)$ \\
& Backcourt player & $11.93(1.9)$ \\
& Playmaker & $13.02(1.5)$ \\
& Winger & $12.22(2.2)$ \\
& Pivot & $12.29(20)$ \\
\hline Freedom from Worry & Goalkeeper & $9.02(2.8)$ \\
& Backcourt player & $8.88(2.6)$ \\
Motivation & Playmaker & $9.81(2.8)$ \\
& Winger & $9.51(2.6)$ \\
& Pivot & $10.08(2.6)$ \\
\hline & Goalkeeper & $11.64(2.1)^{*}$ \\
& Backcourt player & $12.16(2.0)$ \\
& Playmaker & $12.58(1.7)$ \\
& Winger & $12.83(1.7)$ \\
& Pivot & $12.24(2.0)$ \\
\hline & Goalkeeper & $12.40(2.2)$ \\
& Backcourt player & $12.61(2.2)$ \\
& Playmaker & $13.48(2.2)$ \\
& Winger & $12.70(2.7)$ \\
& Pivot & $13.08(2.2)$ \\
\hline & & \\
& & \\
& &
\end{tabular}

Note: $* \mathrm{p}<.05, * * \mathrm{p}<.01$

Table 3 Coping by playing positions $(n=287)$

Results in Table 3 conclude that Concentration $(\mathrm{F}=2.612 \mathrm{p}<.05)$ and Confidence/Achievement motivation $(\mathrm{F}=3.067 \mathrm{p}<.05)$ showed significant differences between mean values of coping scales by playing positions. High value of Concentration was measured in the playmakers $(\mathrm{M}=13.02)$, which was significantly higher than in any other positions $\left(\mathrm{M}_{\text {pivot }}=12.29, \mathrm{M}_{\text {winger }}=12.22, \mathrm{M}_{\text {goalkeeper }}=12.05\right.$ and $\mathrm{M}_{\text {backcourt player }}=11.93$ ). Albeit not significantly, but playmakers also achieved the highest scores in Coping with Adversity $(\mathrm{M}=11.67)$, Peaking under Pressure $(\mathrm{M}=12.75)$, Goal Setting and Mental Preparation $(\mathrm{M}=12.33)$ and Coachability $(\mathrm{M}=13.48)$. Wingers produced the highest values of Confidence and Achievement 
Motivation ( $\mathrm{M}=12.83)$, that is, all other playing positions achieved significantly lower scores on this scale $\left(\mathrm{M}_{\text {playmaker }}=12.58, \mathrm{M}_{\text {pivot }}=12.24\right.$, and $\mathrm{M}_{\text {backcourt player }}=12.16$ $\left.\mathrm{M}_{\text {goalkeeper }}=11.64\right)$.

\section{Discussion}

The aim of the present study was to complete the growing contemporary literature, and to study differences in coping strategies by age groups and gender in a sample of Hungarian handball players. The research also focused on differences measured between handball players by different playing positions. In the analyses, the scales of the standardized measurement instrument of ACSI- 28 by Smith and colleagues (1993) supported some of our hypotheses on gender, age and playing positions' differences among junior handball players.

The present study showed that Hungarian junior handball players reached high scores in Coachability, Peaking under Pressure and Confidence/Achievement Motivation, this means that junior players in general pay attention to and follow their coaches and that feedback is especially important to them. They are also confident and positively motivated, consistently give their maximum during practices and competitions and they work hard to improve their skills. Furthermore they are able to perform well under pressure and they feel challenged rather than challenged by pressure situations

The lowest mean values - from all scales - were measured in Freedom from Worry scale in the present sample, which means that the players tend to worry about how their performance is valued by others. Being worried during performance can imply a psychological burden. In case of team sports, opinions and judgments of peers can have a great influence on young athlete' performance, as the importance of social evaluation increase at this age.

In accordance with the research of Gyömber et al. (2015), but contradicting the research of Révész (2008), female junior handball players in our study reached higher values of Coachability than males. For female players, information and instruction from the coach and external reinforcement are of crucial importance and they can also take constructive criticism better than male handball players.

Furthermore, our results slightly differ from that of Révész (2008) and Gyömbér (2015), because our findings show that females score higher on Goal Setting/Mental Preparation than males. This can mean that female handball players do not prepare for competitions only physically but also mentally. Females tend to consider the performance itself and the path leading to successful performance as well.

Similarly to the research of Révész (2008) and Gyömbér (2015), the study showed gender differences, males scored significantly higher in Coping with Adversity and Freedom from Worry than females. Male handball players perform better under pressure, challenge inspires them on a higher level than females. Moreover, they are not overtaken by worry if their performance does not correspond 
to their level of fitness; neither do they worry about how others judge their performance after a competition.

In the age-group based analyses, similarly to the available literature findings by Goudas, 1998; Wapels, 2003, Bebetsos and Antoniu, 2003; Révész, 2008; Géczi, 2009; and Gyömbér et al, 2015, the oldest junior players reached the highest scores on coping scales in our sample, that is, junior handball players worry less about the perception of their performance. Furthermore, the youngest handball players scored the highest onCoachability, similarly to the findings of Révész (2008), Géczi (2009) and Tóth et al. (2011), who showed that the oldest age group produced the lowest values of this scale. This means younger players tend to follow the coaches' instructions more likely than the older ones, since the personality development at younger age is dominated by the impact of peers and teammates, and the values are more focused on this social atmosphere. Due to this psychologically critical ageperiod young athletes tend to push the boundaries, find the limits of the coach and fight for their perceived rights against the coaches.

Our findings showed that, similarly to previous research findings (Coetzee et al., 2006, Jooste et al., 2014), there were no significant differences between the handball post, except the playmakers in the Concentration scale, while the goalkeeper reached significantly lower scores in Confidence and Achievement Motivation. But, based on works by Vidic\& Burton (2010), Ragab (2015), Vidic, Martin \&Oxhandler (2016), we could see that the professional with constant mental training can decrease stress and increase athletic coping skills.

We concluded that playmakers reached the highest mean values on several scales (Coping with Adversity, Peaking under Pressure, Goal Setting/Mental Preparation, Coachability), and a remarkably high value on the Concentration scale. As one of the leaders of the team, the playmaker must see beyond his or her own play and be able to connect the different players of the team, and also follow the coaches' instructions. Playmakers need to coordinate his/her own plays and to fulfill various tasks during performance. In many teams, the playmakers usually fill the team leader position. This means, playmakers should have improved coping skills in order to elevate the performance of the whole team.

\section{Conclusion}

With the results of the present study, we would like to draw attention to the fact that for successful preparation, coaches have to consider the players' gender, age and playing position for the improvement of team and individual performance. The knowledge of the athlete's coping skills and their self-assessment? Can contribute to better preparation and are indispensable for successful preparation and performance. When developing and assigning roles in a team, it is advisable to gather information and data on the players' personality and psychological skill sets in order to guarantee them the most suitable role for improved performance. 


\section{References}

1. Bebetsos, E., Bebetsos, G. (2006): Greek Youth Team Handball Players and Their Satisfaction Levels. European Handball Magazine, p. 1-9

2. Bognár J. ,Géczi G. , Vincze G., Szabo A. (2009): Coping Skills, Motivational Profiles, and Perceived Motivational Climate in Young Elite Ice Hockey and Soccer Players. International Quarterly of Sport Science, 1.

3. Ciocan D. M., Fleancu L.J., Ciocan V.C. (2012): Study on Psychological Skills of Professional Female Volleyball Players. Scientific Journal of Education, Sports, and Health, No.1. No. 1, Vol. XIII.

4. Coetzee B., Grobbelaar H.W., Gird C.C. (2006): Sport psychological skills that distinguish successful from less successful soccer teams. Journal of Human Movement Studies, 51., p. 383-401

5. Csáki I., SzakályZs., Fózer-Selmec B.B., Selmeci Kiss Z., Bognár J. (2017): Psychological and Anthropometric Characteristics of a Hungarian Elite Football Academy's Players. Physical Culture and Sport Studies and Research, Vol. LXXIII, p. 15-26. DOI: https://doi.org/10.1515/pcssr-2017-0002

6. Géczi, G. (2009): Success and Talent Development as Indicated by Motor Tests and Psychometric Variables of U18 Ice Hockey Players. PhD dissertation,SE, Budapest

7. Goudas, M. (1998): Motivational Climate and Intrinsic Motivation of Young Basketball Players. Perceptual and Motor Skills, 86. 323-327 DOI: https://doi.org/10.2466/pms.1998.86.1.323

8. Grobbelaar H.W, Eloff M. (2011): Psychological skills of provincial netball players in different playing positions. South African Journal for Research in Sport. Physical Education and Recreation, Vol. 33. 2, p. 45 - 58 DOI: https://doi.org/10.4314/sajrs.v33i2.69689

9. Gyömbér, N., Kovács, K. (2012): Fejben dől el. Sportpszichológia mindenkinek. NoranLibro Publisher, Budapest

10. Gyömbér, N., Kovács, K., Lénárt, Á. (2015): Do psychological factors play a crucial role in sport performance? - Research on personality and psychological variables of athletes in Hungary. Cuadernos de Psicología del Deporte, 16, 1: 223-232

11. Jooste J., Steyn B.J.M., Van den Berg L. (2014): Psychological Skills, Playing Positions and Performance of African Youth Soccer Teams. South African Journal for Research in Sport, Physical Education and Recreation, 36. 1: 85-100

12. Kiss, Z., Fozer-Selmeci, B., Csáki, I., Bognár, J. (2015): Bentlakó Labdarúgó Korosztályok Pszichés Mentális Jellemzői. Mentálhigiéné és Pszichoszomatika 16, 4, p. 331-347 DOI: https://doi.org/10.1556/0406.16.2015.4.2

13. Kruger A., Pienaar A.E. (2014): Gender differences in the sport psychological skills profile of adolescent sport participants: original research. International Sport Med Journal, Vol. 15., 4., p. 474-482

14. Leunes, A. (2011) Introducing Sport Psychology. A practical guide. IconBooksLtd, London 
15. Orosz R. (2009) A labdarúgó tehetség kibontakoztatását befolyásoló pszichológiai tényezők vizsgálata. Doctoral Dissertation. DE, Debrecen

16. Ragab M. (2015): The Effects Of Mental Toughness Training on Athletic Coping Skills and Shooting Effectiveness for National Handball Players. Science, Movement and Health, Vol. XV, 2., 431-435

17. Révész, L. (2008): A tehetséggondozás, a kiválasztás és a beválás néhány kérdésének vizsgálata az úszássportágban, Doctoral Dissertation. SE, Budapest

18. Smith, Ronald E., Smoll, Frank L., Schutz, Robert W., Ptacek, J.T. (1995) Development and validation of a multidimensional measure of sport-specific psychological skills: the Athletic Coping Skills Inventory-28. Journal of Sport \& Exercise Psychology. 17(4), 379-398. DOI:

https://doi.org/10.1123/isep.17.4.379

19. Spieler M., Czech D.R., Joyner A.B., Munkasy B., Gentner N., Long J (2007): Predicting Athletic Success: Factors Contributing to the Success of NCAA Division I AA Collegiate Football Players. Athletic Insight. The Original Journal of Sport Psychology 9. 2.

20. Tóth, L., Géczi, G., Bognár, J. (2011) A versenyszorongás, a sportolói megküzdési stratégiák és az emocionális jellemzők vizsgálata magyar válogatott jégkorongozóknál. Kalokagathia. 49(2-4): 129-147.

21. Vidic Z, Burton D. (2010): Examining the Impact of a Systematic Goal-Setting Program for Collegiate Women's Tennis Players. The Sport Psychologist, 24, 427-447. DOI: https://doi.org/10.1123/tsp.24.4.427

22. Vidic Z., St. Martin M., Oxhandler R. (2016): Mindfulness Intervention with a U.S. Women's NCAA Division I Basketball Team: Impact on Stress, Athletic Coping Skills and Perceptions of Intervention Authors. The Sport Psychologist, 0.0. DOI: https://doi.org/10.1123/tsp.2016-0077

23. Waples, S.B. (2003): Psychological characteristics of elite and non-elite level gymnasts. Doctoral Dissertation. Texas A\&M University. 